\title{
OCENA WŁAŚCIWOŚCI FIZYCZNYCH I MECHANICZNYCH KOMPOZYTU GLINOWEGO Z DODATKIEM SŁOMY POD KĄTEM WYKORZYSTANIA W BUDOWNICTWIE
}

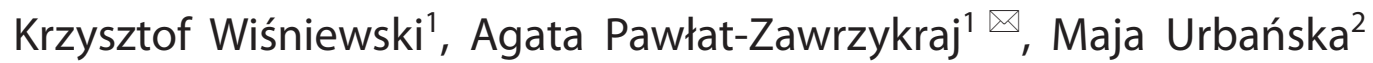 \\ ${ }^{1}$ Wydział Budownictwa i Inżynierii Środowiska, Szkoła Główna Gospodarstwa Wiejskiego w Warszawie, Warszawa \\ 2 Skanska S.A.
}

\begin{abstract}
STRESZCZENIE
W pracy przedstawiono wyniki badań wybranych właściwości fizycznych i mechanicznych kompozytu glinowego z dodatkiem słomy i piasku kwarcowego. Zawartość gliny w badanych próbkach wahała się od 63 do 53\%, słomy 5-13\%, piasku 4-10\%. Wykonano badanie skurczu, gęstości, wytrzymałości na zginanie oraz wytrzymałości na ściskanie. Uzyskane wyniki wskazują na korzystny wpływ dodatków na badane właściwości. Wraz ze wzrostem zawartości słomy oraz piasku kwarcowego malał skurcz suszenia, rosła wytrzymałość na ściskanie i zginanie. Najlepsze wyniki uzyskano dla próbek zawierających 58\% gliny, 9\% słomy, $6 \%$ - piasku, 27\% wody. Uzyskane wyniki badań wskazują na przydatność badanego kompozytu jako materiału do wznoszenia konstrukcji nośnych budynków.
\end{abstract}

Słowa kluczowe: glina, słoma, materiały budowlane, skurcz, wytrzymałość

\section{WSTĘP}

Budownictwo z gliny znane jest i stosowane od dawna, ale w ostatnim czasie zyskuje na popularności m.in. z uwagi na swój niski stopień energochłonności. Glina jako materiał nieprzetworzony uznawana jest za produkt przyjazny dla środowiska naturalnego, a także materiał sprzyjający wytworzeniu odpowiedniego mikroklimatu wewnątrz pomieszczeń w budynkach wznoszonych z tego materiału (Hyła i Kupiec-Hyła, 1994; Kamieniarz, 2010; Szuba, 2011; Minke, 2012; Backiel-Brzozowska，2014; Wiśniewski，Geniusz i Pawłat-Zawrzykraj, 2018).

Budownictwo z gliny w Polsce przechodziło różne koleje losu np. w latach czterdziestych i pięćdziesiątych
XX wieku powstało kilkadziesiąt obiektów budownictwa mieszkaniowego i inwentarskiego, ale nigdy budownictwo z gliny nie stało się powszechne. Ten rodzaj technologii wznoszenia budynków powszechnie był uznawany za budownictwo dla ubogich, substandardowe, realizowane często w sposób nieprawidłowy.

Obecnie rozwój technologii stosowanych w budownictwie jest w dużej mierze wynikiem dostosowywania się polskiego prawodawstwa do standardów europejskich. Te zaś są odzwierciedleniem dążenia do budownictwa energooszczędnego, przyjaznego środowisku naturalnemu nie tylko w czasie eksploatacji, ale także na etapie produkcji materiałów budowlanych, a nawet $\mathrm{w}$ czasie rozbiórki i utylizacji następującej po zużyciu technicznym. Jednym z rozwiązań wy-

$凶$ agata_pawlat_zawrzykraj@sggw.pl 
chodzących naprzeciw tego rodzaju potrzebom rynku budowlanego może być glina - naturalny materiał, jak już wspomniano, niewymagający dużych nakładów energetycznych, a w związku z tym dużych kosztów produkcji, transportu i robocizny (Wiśniewski i in., 2018). Większość realizowanych budynków wznoszona jest systemem gospodarczym. Niestety zainteresowanie firm budowlanych, głównie ze względu na mała rentowność tego rodzaju realizacji, jest nadal niewielkie.

Norma branżowa BN-62/6738-02, dotycząca budownictwa $\mathrm{z}$ gliny, określa masy gliniane jako mieszaninę gliny $\mathrm{z}$ wypełniaczami mineralnymi bądź organicznymi. Mogą być one zastosowane do produkcji materiałów o różnym przeznaczeniu, zarówno jako konstrukcyjne bloczki ścienne, belki, nadproża drzwiowe oraz okienne, jak i bloczki ścienne do ścian działowych i wypełniających, płyty ocieplające, płyty stropowe i dachowe. Norma narzuca ograniczenia w budowlanym wykorzystaniu mas glinianych do budynków o maksymalnie trzech kondygnacjach, o małym i średnim zawilgoceniu.

Gliny charakteryzują się dość znacznym zróżnicowaniem składu chemicznego i mineralogicznego, który wpływa bezpośrednio na cechy mechaniczne i fizyczne materiałów z nich wytwarzanych. $\mathrm{Z}$ tego względu każdorazowo należy przeprowadzić badania gęstości objętościowej, wytrzymałości na ściskanie, wrażliwości na suszenie i skurcz suszenia. Zgodnie z normą BN-62/6738-02 wyróżniane są trzy rodzaje gliny: ciężka, średnio ciężka, lekka.

Określenia te odnoszą się do masy $1 \mathrm{~m}^{3}$ kompozytów z gliny i tak dla:

- glin ciężkich średnia gęstość wynosi do $1800 \mathrm{~kg} \cdot \mathrm{m}^{-3}$,
- glin średnio ciężkich średnia gęstość wynosi 1200$-1700 \mathrm{~kg} \cdot \mathrm{m}^{-3}$

- glin lekkich średnia gęstość wynosi $600-1200 \mathrm{~kg} \cdot \mathrm{m}^{-3}$. W publikacjach autorstwa Hyły i Kupiec-Hyła (1994) oraz Minke (2012) analizowano głównie rozwiązania z zastosowaniem tzw. glin lekkich. W pracy wykorzystano kompozyty glinowe z gliny odpowiadającej parametrom gliny średnio ciężkiej, z różną ilością dodatków włóknistych (słoma cięta) i piasku kwarcowego w celu odwrażliwienia gliny na możliwość pękania w trakcie suszenia. O ile piasek kwarcowy wpływa na skurcz suszenia i ograniczenie możliwości pękania kompozytu glinowego, o tyle dodatek sieczki słomianej miał za zadanie poprawę właściwości cieplnych i mechanicznych (Racięcki, 1962).

Celem pracy jest zbadanie wybranych właściwości fizycznych oraz mechanicznych kompozytu glinowego o różnej zawartości słomy oraz piasku w celu określenia jego przydatności do celów budowlanych.

\section{MATERIA I METODY}

Do wykonania badania wykorzystano glinę pochodzącą z nadkładu gruntów Kopalni Węgla Brunatnego „Bełchatów”. Osady występujące w rejonie bełchatowskiej odkrywki zaliczane są do osadów neogenu poznańskiego, kompleksu ilasto-piaszczystego, który tworzy kilka pokładów zalegających w uskokach brzeżnych i osiągających grubość 40-50 m (Ratajczak i Hycnar, 2017).

Podstawowym minerałem użytej gliny jest beidelit z nieznaczną zawartością kwarcu oraz kaolinitu (Hycnar, Jończyk i Ratajczak, 2017). Skład chemiczny badanego materiału przedstawiono $\mathrm{w}$ tabeli 1.

Tabela 1. Skład chemiczny gliny

Table 1. The chemical composition of the clay

\begin{tabular}{lccc}
\hline $\begin{array}{l}\text { Składniki } \\
\text { Components }\end{array}$ & $\begin{array}{c}\text { Zawartość [\%wag.] } \\
\text { Content [wt\%] }\end{array}$ & $\begin{array}{c}\text { Składnik } \\
\text { Components }\end{array}$ & $\begin{array}{c}\text { Zawartość [\%wag.] } \\
\text { Content [wt\%] }\end{array}$ \\
\hline $\mathrm{SiO}_{2}$ & 61,57 & $\mathrm{TiO}_{2}$ & 0,47 \\
$\mathrm{Al}_{2} \mathrm{O}_{3}$ & 26,48 & $\mathrm{P}_{2} \mathrm{O}_{5}$ & 0,16 \\
$\mathrm{Fe}_{2} \mathrm{O}_{3}$ & 3,57 & $\mathrm{SO}_{3}$ & 0,10 \\
$\mathrm{CaCO}_{3}$ & 2,54 & $\mathrm{Na}_{2} \mathrm{O}$ & 0,06 \\
$\mathrm{CaO}$ & 1,42 & $\mathrm{MnO}$ & 0,02 \\
$\mathrm{MgO}$ & 1,04 & straty prażenia - loss on ignition & 3,86 \\
$\mathrm{~K}_{2} \mathrm{O}$ & 0,65 & części organiczne - organic components & 0,50 \\
\hline
\end{tabular}


Poszczególne etapy przygotowania gliny obejmowały:

- suszenie w suszarce laboratoryjnej (temperatura suszenia $60^{\circ} \mathrm{C}$, czas suszenia $48 \mathrm{~h}$ ),

- rozdrobnienie na drobne frakcje w młynie kulowym,

- przesianie przez sito o wielkości oczek $2 \mathrm{~mm}$.

Uzyskany materiał podzielono na cztery części na potrzeby czterech serii badań, następnie dodano w różnych proporcjach piasek, słomę i wodę. Funkcję zbrojenia rozproszonego dla bloczków wykonanych z gliny pełniła słoma żytnia, której łodygi pocięto na 2-3-centymetrowe włókna.

Kruszywo to piasek kwarcowy frakcji $1 \mathrm{~mm}$. Procentową zawartość gliny, słomy, piasku i wody w poszczególnych seriach badań $\mathrm{w}$ przedstawiono w tabeli 2. tym kapilary mają mniejszy przekrój i utrudniają swobodne odparowywanie wody. Z tego powodu wymagają one dłuższego suszenia niż gliny o mniejszej zawartości substancji ilastych. Tę niekorzystną sytuację w przypadku glin tłustych można zmienić, dodając tzw. materiałów schudzających, np. piasku kwarcowego lub granulowanego materiału ceramicznego (np. gruz ceglany).

Badanie skurczu zostało wykonane na belkach o wymiarach $40 \times 40 \times 160 \mathrm{~mm}$. Metoda badania skurczu polegała na określenie zmiany odległości nacięć wykonanych na belce przed suszeniem i po całkowitym wysuszeniu. Pomiary odległości między nacięciami zmierzono za pomocą suwmiarki elektronicznej z dokładności do $0,5 \mathrm{~mm}$. Procentowy skurcz próbek obliczono zgodnie ze wzorem (1):

Tabela 2. Skład ilościowy kompozytu glinowego

Table 2. Quantitative composition of the clay composite

\begin{tabular}{ccccc}
\hline \multirow{2}{*}{$\begin{array}{c}\text { Nr serii } \\
\text { Series no. }\end{array}$} & \multicolumn{4}{c}{ Skład mieszanki - Mixture composition [\%] } \\
\cline { 2 - 5 } & $\begin{array}{c}\text { glina } \\
\text { clay }\end{array}$ & $\begin{array}{c}\text { słoma } \\
\text { straw }\end{array}$ & $\begin{array}{c}\text { piasek } \\
\text { sand }\end{array}$ & $\begin{array}{c}\text { woda } \\
\text { water }\end{array}$ \\
\hline I & 68 & 0 & 0 & 32 \\
II & 63 & 5 & 4 & 28 \\
III & 58 & 9 & 6 & 27 \\
IV & 53 & 13 & 10 & 24 \\
\hline
\end{tabular}

$\mathrm{Na}$ potrzeby niniejszego badania uformowano 12 próbek o wymiarach $100 \times 100 \times 100 \mathrm{~mm}$ oraz 12 belek o wymiarach $40 \times 40 \times 160 \mathrm{~mm}$, które następnie dla uniknięcia gwałtownego skurczu poddano dwuetapowemu powolnemu suszeniu do momentu uzyskania stałej masy. W pierwszej kolejności (48 h) próbki suszono w temperaturze pokojowej, w końcowej fazie $(24 \mathrm{~h})-\mathrm{w}$ temperaturze $105^{\circ} \mathrm{C}$. Przyjęty sposób suszenia wynikał z tego, że próbki zerowe bez dodatków w czasie suszenia wykazywały bardzo silny skurcz i skłonność do pękania (rys. 1). Szybkość dyfuzji wody z wnętrza próbek na zewnątrz jest zależna od zawartości substancji ilastych, co jest związane m.in. z wielkością kapilar. Im glina ,jest bardziej thusta", czyli im więcej minerałów ilastych,

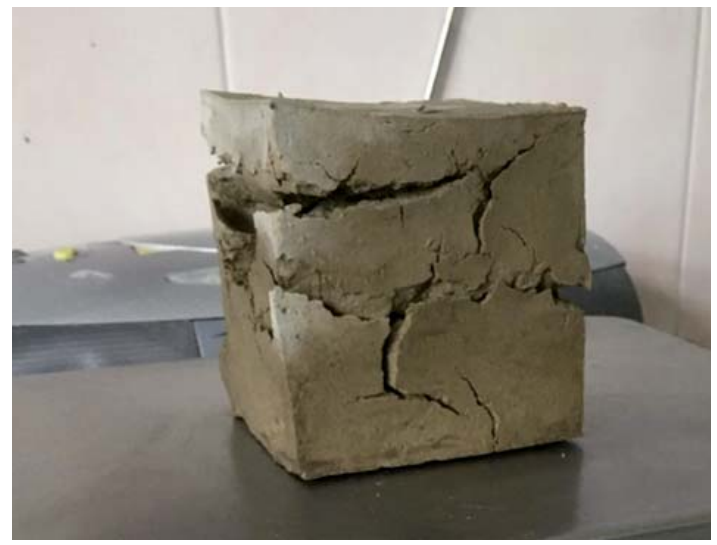

Rys. 1. Silne spękania próbki w wyniku skurczu suszenia

Fig. 1. Strong cracks of the sample as a result of contraction of the drying 
$S=\frac{l-l_{s}}{l} \cdot 100 \%$

gdzie:

$S-\operatorname{skurcz}[\%]$,

$l$ - odległość między poprzecznymi nacięciami po uformowaniu próbki [mm],

$l_{S}$ - odległość między poprzecznymi nacięciami po wyschnięciu próbki [mm].

Gęstość objętościowa próbek sześciennych oraz belek została obliczona zgodnie ze wzorem (2), z wykorzystaniem wartości uzyskanych przed suszeniem i po ich wysuszeniu.

$\rho_{0}=\frac{m}{v}$

gdzie:

$\rho_{0}-$ gęstość objętościowa $\left[\mathrm{kg} \cdot \mathrm{m}^{-3}\right]$,

$m$ - masa próbki $[\mathrm{kg}]$,

$V$ - objętość próbki $\left[\mathrm{m}^{3}\right]$.

Badanie wytrzymałości na zginanie wykonano na próbkach belek o wymiarach $40 \times 40 \times 160 \mathrm{~mm}$. Przyjęto przypadek obciążenia działającego na środek belki. Na podstawie uzyskanej wartości siły zginającej obliczona została wytrzymałość na zginanie belki zgodnie ze wzorem (3).

$f_{c f}=\frac{M_{\max }}{W_{z}}$

gdzie:

$f_{c f}$-wytrzymałość na zginanie $\left[\mathrm{kN} \cdot \mathrm{mm}^{-2}\right]$,

$M_{\max }-$ maksymalny moment zginający [kNmm],

$W_{z}$ - wskaźnik wytrzymałość na zginanie $\left[\mathrm{mm}^{3}\right]$.

Wskaźnik wytrzymałości na zginanie obliczono według wzoru (4).

$W_{z}=\frac{b \cdot h^{2}}{6}$

gdzie:

$W_{z}$ - wskaźnik wytrzymałość na zginanie $\left[\mathrm{mm}^{3}\right]$,

$b$ - szerokość belki [mm],

$h$-wysokość belki [mm].
Maksymalny moment zginający obliczono ze wzoru (5).

$M_{\text {max }}=\frac{P \cdot l}{4}$

gdzie:

$M_{\max }$ - maksymalny moment zginający [kNmm],

$P$ - siła niszcząca $[\mathrm{kN}]$,

$l$ - odległość między podparciami belki [mm],

Badanie wytrzymałości gliny na ściskanie przeprowadzono na próbkach o wymiarach $100 \times 100 \times 100 \mathrm{~mm}$. Celem było wyznaczenie maksymalnego naprężenia ściskającego, jakie jest w stanie przenieść sześcienna próbka kompozytu glinowego. Badanie wykonano w maszynie wytrzymałościowej, w której jednostajnie zwiększano siłę niszczącą do momentu zniszczenia próbek. Wytrzymałość na ściskanie obliczono zgodnie ze wzorem (6).

$f_{c}=\frac{F}{A_{c}}$

gdzie:

$f_{c}$ - wytrzymałość na ściskanie [MPa],

$F$ - maksymalne obciążenie przy zniszczeniu [N],

$A_{c}$ - pole przekroju poprzecznego próbki, na które działa siła ściskająca $\left[\mathrm{mm}^{2}\right]$.

\section{WYNIKI}

Na podstawie wykonanych badań kompozytu glinowego, składającego się z gliny, ciętej słomy, piasku kwarcowego i wody (tab. 2), uzyskano wyniki podstawowych właściwości fizycznych i mechanicznych badanych próbek (tab. 3 i 4). W pierwszej kolejności ustalono gęstość objętościową próbek o różnym składzie dodatków do gliny. Średnia gęstość próbek sześciennych po wysuszeniu wykazuje tendencję wzrostową wraz ze zwiększeniem dodatku piasku kwarcowego (serie II i III) w stosunku do gliny bez dodatków, ale jednocześnie z uwagi na zwiększanie zawartość ciętej słomy w stosunku do piasku kwarcowego gęstość badanych próbek nieznacznie maleje, co zauważono w przypadku serii IV (rys. 2). 


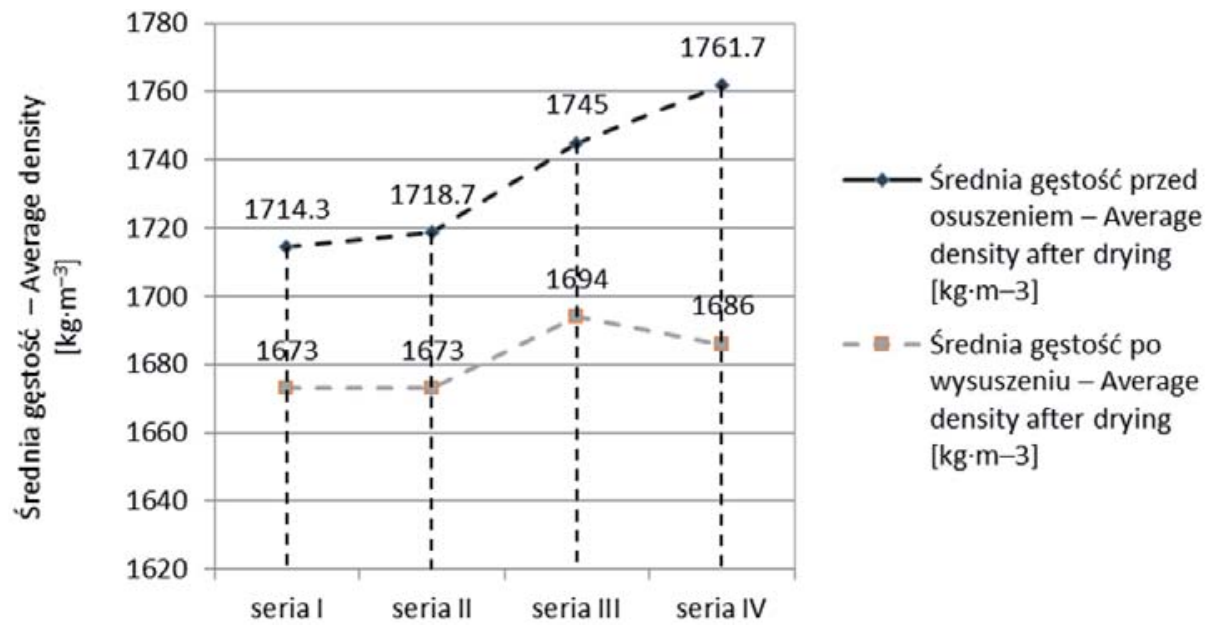

Rys. 2. Średnia gęstość dla próbek sześciennych

Fig. 2. The average density of the cube samples after drying

Skurcz kompozytów glinowych ma istotne znaczenie przy wznoszeniu elementów konstrukcyjnych (ścian zewnętrznych i wewnętrznych). Zbyt duży skurcz może prowadzić do powstawania rys, pęknięć ścian, a w konsekwencji do zmniejszenia wytrzymałości i uszkodzenia budynku. Na podstawie uzyskanych wyników badania skurczu można stwierdzić, że dodatki w postaci ciętej słomy i piasku kwarcowego wpływają na zmniejszenie skurczu badanych próbek kompozytu glinowego (tab. 3). Podobny efekt można uzyskać, stosując dodatek popiołu lotnego (Wiśniewski i Ziółkowska, 2014). Jednakże dodatek popiołu wpływa na zmniejszenie wytrzymałości na ściskanie i zginanie. W przypadku dodatków w postaci ciętej słomy i piasku kwarcowego obserwuje się zwiększenie średniej wytrzymałości na ściskanie w porównaniu do próbek zerowych. Maksymalną wytrzymałość na ściskanie otrzymano dla próbek serii III (2,18 MPa), a najmniejszą dla próbek serii I, czyli zerowych $(1,81 \mathrm{MPa})$ - rysunek 3 .

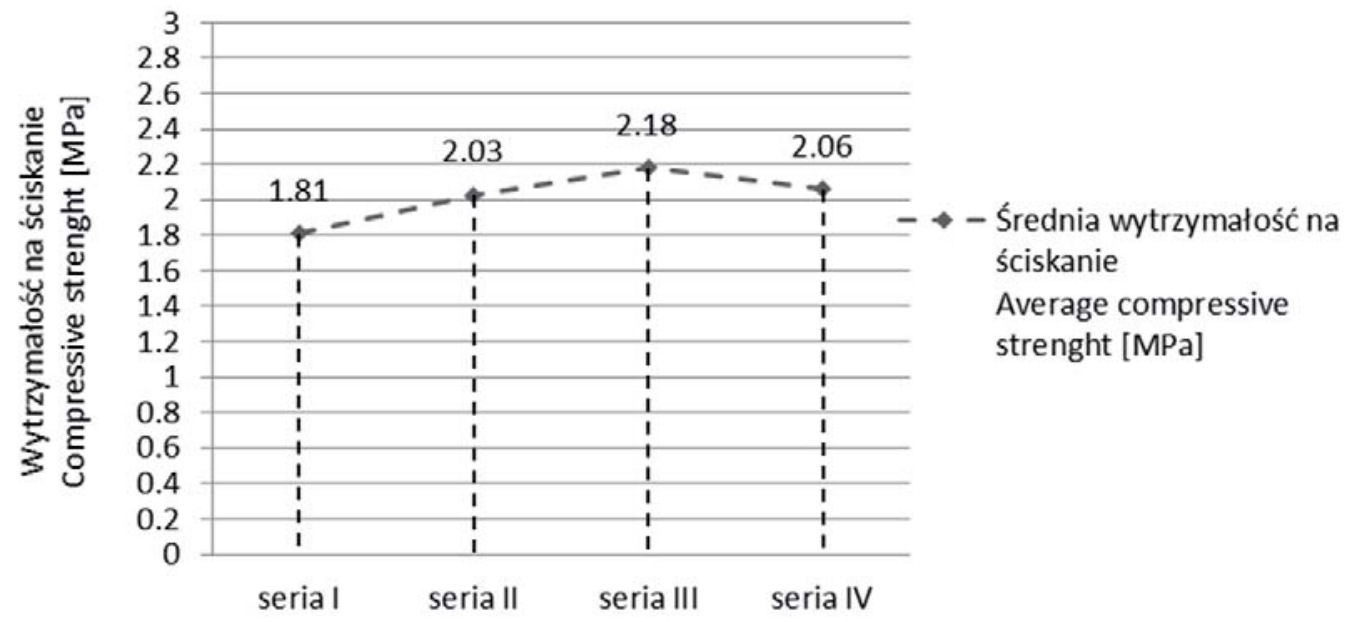

Rys. 3. Wpływ składu badanych próbek sześciennych na ich średnią wytrzymałość na ściskanie

Fig. 3. Influence of compositions of the cube samples on their average compressive strength 


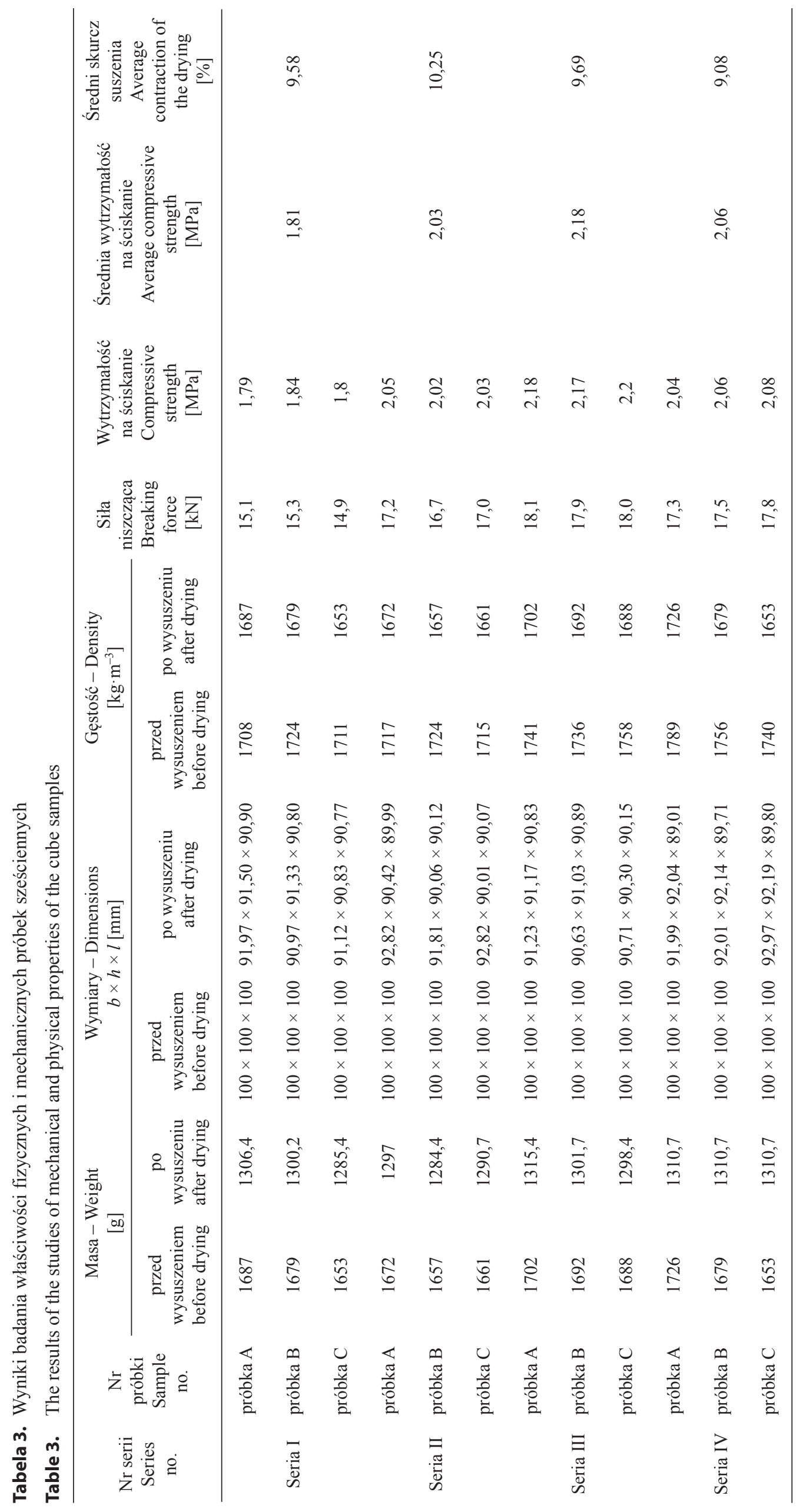




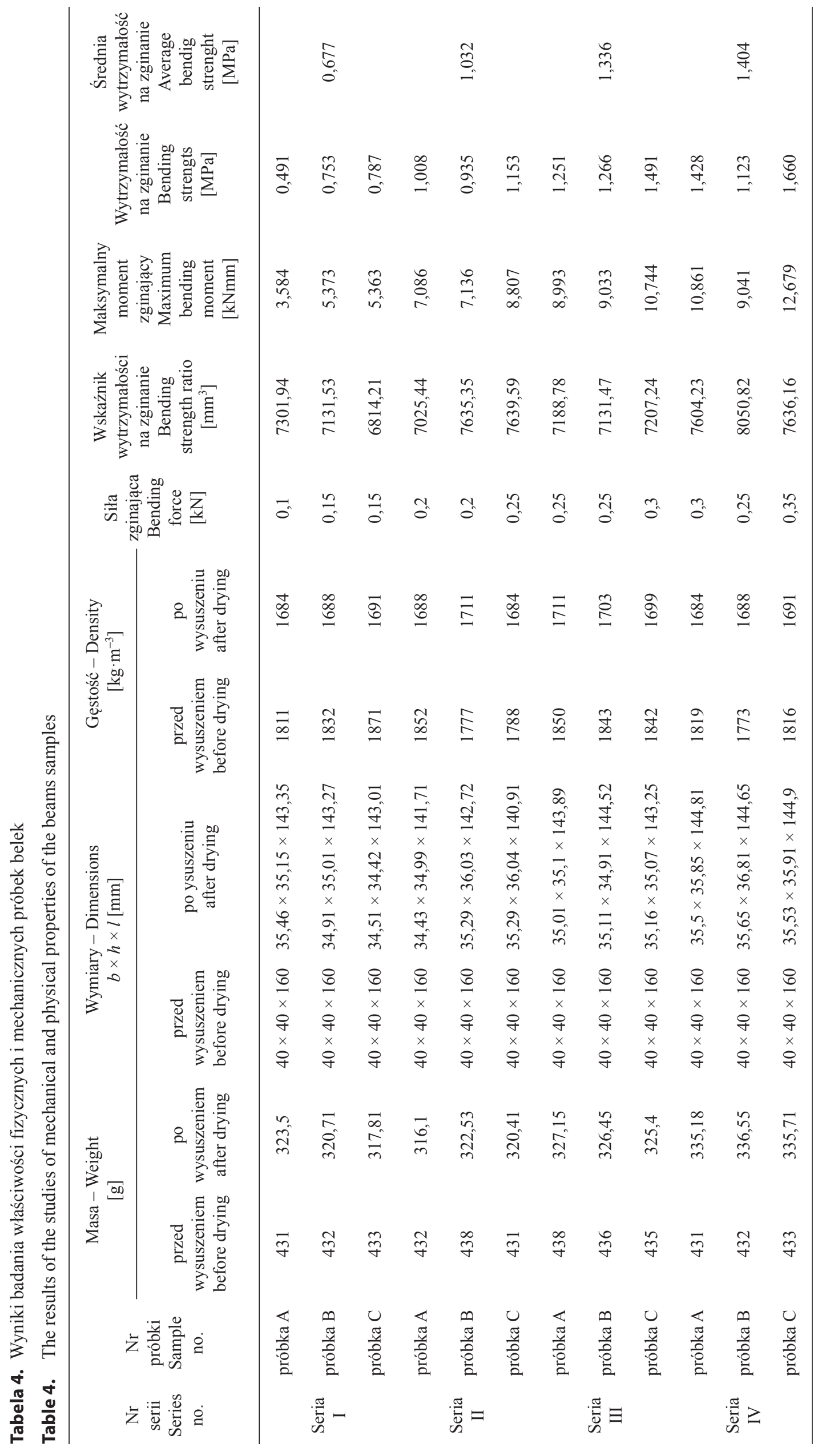


Podobny efekt można zaobserwować w przypadku badań wytrzymałości na zginanie, w których dodatek słomy i piasku wpływa na zwiększanie wytrzymałości badanych próbek. Uzyskano odpowiednio wytrzymałość na zginanie od 0,68 MPa dla próbek serii I, 1,03 dla serii II, 1,34 dla serii III i 1,4 MPa dla próbek serii IV (tab. 4, rys. 4). bez dodatków (seria I - 1,81 MPa, seria II - 2,03 MPa, seria III - 2,18 MPa, seria IV - 2,06 MPa).

4. Pozytywnym zjawiskiem jest zwiększenie wytrzymałości na ściskanie wraz ze wzrostem ilości zastosowanych dodatków do granicznych wartości uzyskanych dla badanych próbek serii III. W przypadku próbek serii IV przyjęta zawartość dodatków wpłynęła na nieznaczne zmniejszenie wytrzymałości na ściskanie.

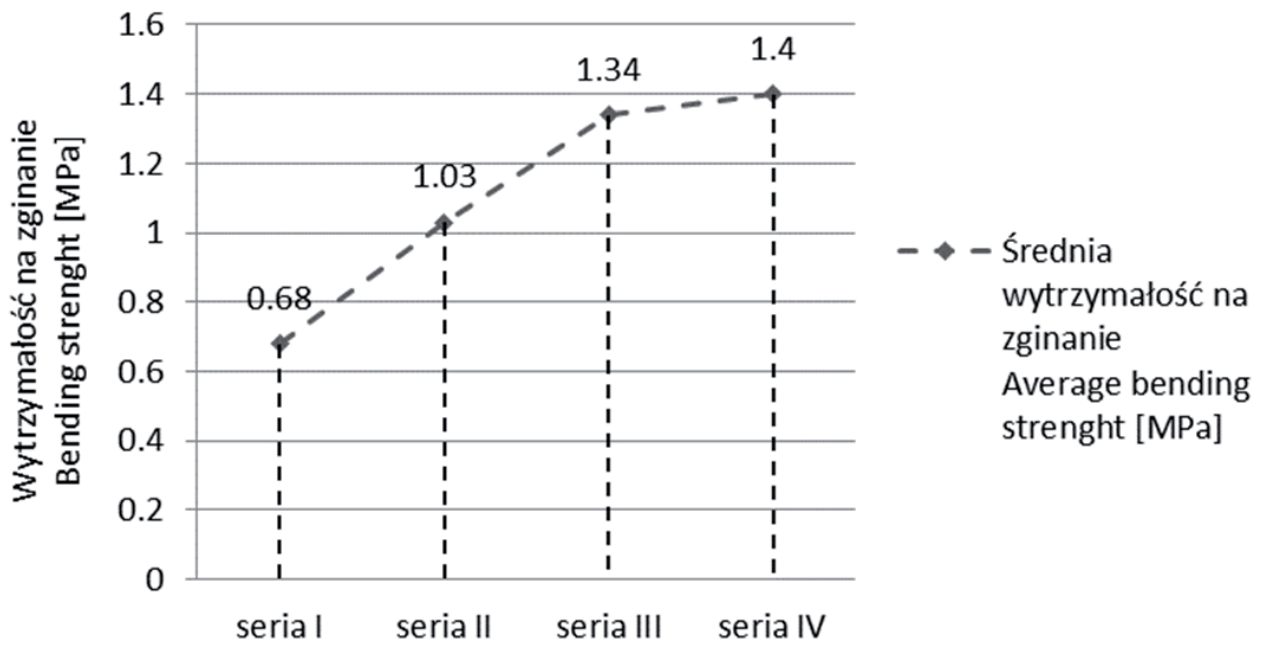

Rys. 4. Wpływ składu badanych próbek belek na ich średnią wytrzymałość na zginanie

Fig. 4. Influence of compositions of the beams samples on their average bending strength

\section{WNIOSKI}

1. Stwierdzono istotny wpływ dodatku słomy i piasku kwarcowego w różnych proporcjach na zmianę gęstości objętościowej. Wraz ze wzrostem udziału tych dodatków obserwuje się stopniowe zwiększanie gęstości objętościowej: seria II $-1673 \mathrm{~kg} \cdot \mathrm{m}^{-3}$, seria III $-1694 \mathrm{~kg} \cdot \mathrm{m}^{-3}$. W przypadku serii IV, gdzie udział słomy wynosił $13 \%$, a piasku $10 \%$, gęstość objętościowa uległa obniżeniu do poziomu $1686 \mathrm{~kg} \cdot \mathrm{m}^{-3}$.

2. Na podstawie uzyskanych wyników badania skurczu można stwierdzić, że stopniowe zwiększanie ilości dodatków do gliny przyczynia się do zmniejszenia skurczu suszenia i pęknięć próbek.

3. Zauważalne jest zwiększenie wytrzymałości kompozytu glinowego wraz ze wzrostem zawartości słomy i piasku kwarcowego w porównaniu do gliny
5. Za optymalny skład kompozytu glinowego można przyjąć, zgodnie z uzyskanymi wynikami badań, serię III, tj. próbki o składzie 58\% gliny, 9\% słomy, 6\% piasku kwarcowego, 27\% wody. Badanie próbek o takim składzie wykazało największą wytrzymałość na ściskanie oraz tylko nieznacznie mniejszą wytrzymałość na zginanie w stosunku do próbek serii IV.

6. Uzyskane wyniki potwierdzają możliwość zastosowania kompozytów glinowych do wznoszenia konstrukcji nośnych budynków. Jednakże każdorazowo należy wykonać badania wytrzymałościowe i cech fizycznych, gdyż każda glina charakteryzuje się odmiennymi właściwościami, zależnie od składu chemicznego i mineralogicznego.

7. Zastosowana $\mathrm{w}$ badaniach glina pochodzącą z wyrobiska Kopalni Węgla Brunatnego „Bełchatów” może być wykorzystana $\mathrm{w}$ budownictwie, co m.in. 
wpłynie na zmniejszenie uciążliwości wyrobiska dla środowiska naturalnego.

\section{PIŚMIENNICTWO}

Backiel-Brzozowska, B. (2014). Budownictwo z gliny i słomy - wstępna ocena wybranych aspektów trwałości. Inżynieria Ekologiczna, 40, 208-216.

BN-62/6738-02. Budownictwo z gliny - Masy gliniane.

Hycnar, E., Jończyk, M. W. i Ratajczak, T. (2017). Popioły lotne i iły beidellitowe z Bełchatowa jako składniki mieszanin samozestalających się. Zeszyty Naukowe Instytutu Gospodarki Surowcami Mineralnymi i Energia PAN, 100, 37-48.

Hyła, M. i Kupiec-Hyła, D. (1994). Domy z lekkiej gliny. Kraków: Zarząd Zespołu Jurajskich parków krajobrazowych w Krakowie.

Kamieniarz, M. (2010). Nowe rozwiązanie z zakresu technologii wznoszenia domów z gliny. Czasopismo Techniczne, 18 (107), 279-280.
Minke, G. (2012). Handbuch Lehmbau: Baustoffkunde, Techniken, Lehmarchitektur. Ökobuch. Freiburg: Verlag Staufen.

Racięcki, Z. (1962). Budynki z gliny. Warszawa: Arkady.

Ratajczak, T. i Hycnar, E. (2017). Kopaliny towarzyszace w złożach węgla brunatnego. T. I. Kraków: Instytut Gospodarki Surowcami Mineralnymi i Energią PAN.

Szuba, B. (2011). Stare technologie w nowej szacie architektury ekologicznej. Journal of Ecology and Health, 15 (2), 55-61.

Wiśniewski, K., Gieniusz, W. i Pawłat-Zawrzykraj, A. (2018). Ekonomiczne aspekty wykorzystania gliny w konstrukcji przegród zewnętrznych budynków w porównaniu z wybranym materiałem tradycyjnym. Acta Scientarum Polonorum Architektura, 17 (1), 25-34.

Wiśniewski, K. i Ziółkowska, M. (2014). Wpływ dodatku popiołu lotnego na właściwości kompozytu glinowo-popiołowego. Acta Scientarum Polonorum Architektura, $12(4), 81-89$.

\title{
ASSESSMENT OF PHYSICAL AND MECHANICAL PROPERTIES OF CLAY COMPOSITE WITH ADDITION OF STRAW FOR USE IN CONSTRUCTION
}

\begin{abstract}
The paper presents the results of the research on selected physical and mechanical properties of the clay composite with the addition of straw and quartz sand. The clay content in the tested samples ranged between $63 \%$ and $53 \%$, straw $5-13 \%$, sand $4-10 \%$. The tests of contraction, density, bending strength and compressive strength of clay composite samples were carried out. The obtained results indicate the positive impact of additives on the tested properties. Along with the increase in the content of straw and quartz sand, the contraction of the drying decreased, the compressive and bending strength increased. The best results were obtained for samples containing $58 \%$ of clay, $9 \%$ of straw, $6 \%$ of sand, and $27 \%$ of water. The obtained test results indicate the suitability of the examined composite as a material for erecting load-bearing structures of buildings.
\end{abstract}

Key words: clay, straw, building materials, contraction, strength 
